\title{
ALAT PEMANTAU AIR GALON DAN PENGISI GELAS OTOMATIS BERBASIS ESP8266
}

\author{
Henderi $^{1}$, Ageng Setiani Rafika ${ }^{*}{ }^{2}$, Rani Putri Merliasari ${ }^{3}$ \\ Program Pasca Sarjana Teknik Informatika Universitas Raharja ${ }^{1,2,3}$ \\ Email: henderi@ raharja.info ${ }^{1}$, agengsetianirafika@ raharja.info $^{* 2}$, raniputri@ raharja.info ${ }^{3}$
}

\begin{abstract}
Abstrak
Air minum sangatlah penting bagi tubuh manusia, manusia akan kehilangan konsentrasi bahkan merasa pusing ketika kekurangan air. Pada tempat antrian instansi pemerintah biasanya disediakan tempat air minum, namun ketika seseorang ingin minum tapi air galonnya habis orang tersebut harus memberi tahu petugas tentang hal tersebut, sehingga petugas akan mengisi ulang galon. Ketika ingin minum harus memegangi gelas dan membuka kran air secara manual untuk mengisi gelas dan kemudian menutupnya ketika penuh. Penelitian ini dilakukan dengan metode SDLC dan pengujian Black Box. Penelitian ini membahas tentang merancang sebuah alat pemantau air galon dan pengisi gelas otomatis dengan Wemos D1 yang menggunakan chip ESP8266 sebagai mikrokontroler, load cell sebagai pendeteksi berat sisa air galon dan berat gelas, sensor ultrasonik untuk mengukur jarak gelas dan motor servo untuk menggerakkan tuas kran air. Sisa air galon dapat terpantau melalui jaringan internet menggunakan smartphone, notifikasi terkirim ketika air galon tersisa 2 liter dan gelas dapat terisi secara otomatis sebanyak $250 \mathrm{ml}$.
\end{abstract}

Kata Kunci: ESP8266, load cell, Air Galon, Pengisi Gelas

\begin{abstract}
Drinking water is very important for the human body, humans will lose concentration and even feel dizzy when lacking water. At the North Serpong District Office there are several locations for drinking gallons of water, but when someone wants to drink but the gallon water runs out the person must tell the officer about it, so the clerk will refill the gallon. When you want to drink you have to hold the glass and open the tap manually to fill the glass and then close it when it's full. This research was conducted using the SDLC method and Black Box testing. This study discusses about designing a gallon water monitor and automatic glass filler with Wemos D1 that uses the ESP8266 chip as a microcontroller, load cell as a detector for the weight of the remaining gallon water and the weight of glass, ultrasonic sensors to measure the distance of glass and servo motor to move the water tap lever. The rest of the gallon water can be monitored through the internet using a smartphone, notifications are sent when the remaining 2 liters of gallon water and the glass can be filled automatically as much as $250 \mathrm{ml}$.
\end{abstract}

Keywords: ESP8266, load cell, Gallon Water, Glass Fillers

\section{PENDAHULUAN}

Air minum sangatlah penting bagi tubuh manusia, kekurangan air minum dapat menyebabkan menurunnya konsentrasi, dehidrasi bahkan kepala pusing. Ketika mengantri seperti pada rumah sakit, kantor kecamatan atau instansi pemerintah lainnya biasanya tersedia tempat air minum untuk pengunjung. Ketika air galon habis seseorang harus melapor ke petugas untuk mengganti galon yang kosong dengan yang penuh ketika mencoba untuk minum setelah dilakukan penggantian galon harus memegangi gelas dan membuka kran air minum dan menunggu sampai gelas terpenuhi kemudian menutup kran air minumnya. Hal ini membuat tertundanya penyaluran air ke dalam tubuh dan terasa adanya penurunan kualitas pelayanan karena hal tersebut.

Teknologi yang sedang berkembang saat ini adalah mikrokontroler yang dapat digunakan sebagai pengganti metode konvensional dapat mempermudah aktifitas manusia karena dapat 
digunakan sebagai bantuan untuk melakukan aktifitas rutin secara otomatis contohnya seperti pengendalian perangkat elektronik, sistem pemantauan dan notifikasi. Salah satunya adalah mikrokontroler yang menggunakan chip ESP8266 seperti Wemos D1 yang memiliki fitur WiFi sehingga dapat terhubung ke jaringan internet.

Sensor load cell merupakan transduser yang bekerja sebagai konversi dari berat benda menjadi elektrik, perubahan ini terjadi karena terdapat resistansi pada strain gauge[1]. Air didefinisikan mempunyai massa jenis (densitas) $1 \mathrm{~kg} / \mathrm{liter}$ [2]. Oleh karena itu pemantauan sisa air minum dapat dilakukan dengan menggunakan load cell.

Terdapat beberapa penelitian yang berhubungan dengan penelitian ini seperti pemanfaatan sensor berat, ultrasonik dan notifikasi. Penelitian yang dilakukan oleh Supriyono dkk pada tahun 2015 yang berjudul "Pengukur Tinggi Badan Menggunakan Sensor Ultrasonik Berbasis Mikrokontroler Atmega328 Dengan Output Suara", penelitian tersebut membahas tentang penggunaan sensor ultrasonik untuk mengukur tinggi badan dan Atmega328 sebagai mikrokontrolernya[3]. Penelitian yang dilakukan oleh Apriani dkk pada tahun 2019 yang berjudul "Alat Monitoring Pada Depo Air Minum Biru Cabang Nagrak Kota Tangerang Menggunakan Air Galon Berbasis SMS Gateway", penelitian tersebut membahas tentang pemantauan air galon menggunakan sensor infrared dan pengiriman notifikasi menggunakan SMS[4]. Penelitian yang dilakukan oleh Suhendra dkk pada tahun 2015 yang berjudul "Aplikasi Load Cell Untuk Otomasi Pada Depot Air Minum Isi Ulang”, penelitian tersebut membahas tentang improvisasi pengisian galon pada depot air minum dengan penggunaan load cell sebagai sensor berat pada sebuah timbangan yang akan digunakan sebagai penimbang berat dari galon yang sedang dalam proses pengisian dan menggunakan Arduino Uno sebagai mikrokontrolernya[5].

\section{METODE PENELITIAN}

Dalam merancang alat ini digunakan metode SDLC (System Development Life Cycle), SDLC berfungsi untuk menggambarkan tahapan-tahapan utama dan langkah-langkah dari setiap tahapan yang secara garis besar terbagi dalam lima kegiatan utama, yaitu: analisis, desain, implementasi, pengujian, dan pemeliharaan[6]. Ada pun tahapan yang dilalui dalam perancangan ini.

\subsection{Tahap Analisis}

Pada tahap ini dilakukan analisis terhadap sistem yang berjalan dengan melakukan observasi dan wawancara sehingga ditemukan kekurangan-kekurangan pada sistem tersebut dan memperoleh apa saja yang dibutuhkan oleh pengguna. Ada pun sistem yang berjalan dapat dilihat pada gambar 2.1. 


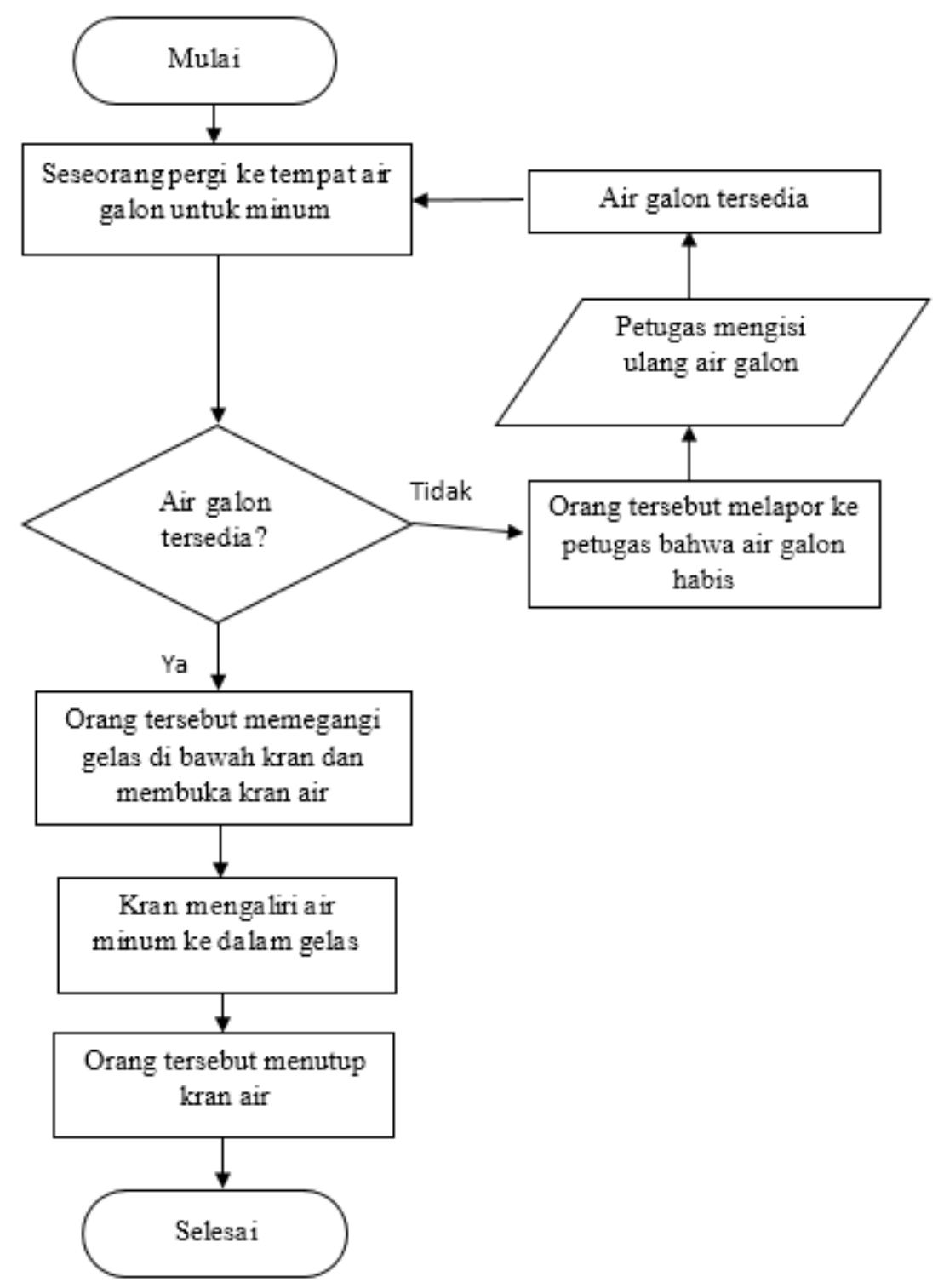

Gambar 1. Flowchart sistem yang berjalan

2.2. Tahap Desain

Pada tahap ini dibuat perancangan sistem yang diusulkan untuk menutupi kekurangankekurangan pada sistem yang berjalan. Perancangan yang dilakukan pada tahap ini pun menggunakan blok diagram dan diagram alir (flowchart) dan dengan referensi dari studi pustaka untuk mempermudah ketika mengimplementasikannya ke dalam alat yang akan dibuat. Dalam perancangan ini juga dibuat blok diagram dari komponen-komponen yang akan digunakan untuk membuat alat ini yaitu menggunakan dua buah Wemos D1, satu Wemos D1 berfungsi sebagai pemantai air galon yang selanjutnya akan disebut sebagai Wemos D1 (1) dan satu Wemos D1 yang berfungsi sebagai pengisi gelas otomatis yang selanjutnya disebut sebagai Wemos D1 (2), load cell untuk mendapat nilat berat, sensor ultrasonik untuk mendeteksi jarak, motor servo MG995 untuk menggerakkan kran air, Adafruit IO sebagai MQTT server, aplikasi MQTT Dashboard untuk menampilkan data sisa air galon dan aplikasi Telegram sebagai media notifikasi. 


\subsubsection{Diagram Blok}

Berikut ini adalah blok diagram yang memperlihatkan susunan komponen yang digunakan.

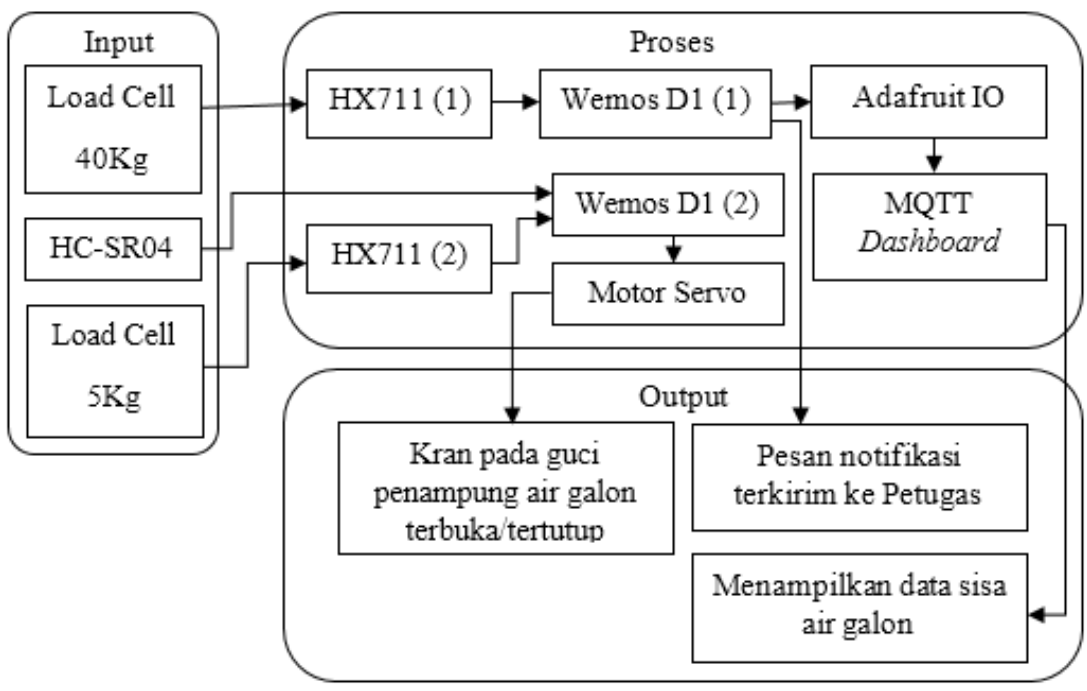

Gambar 2. Diagram blok

\subsubsection{Flowchart Sistem yang Diusulkan}

Berikut ini adalah flowchart rancangan sistem yang diusulkan

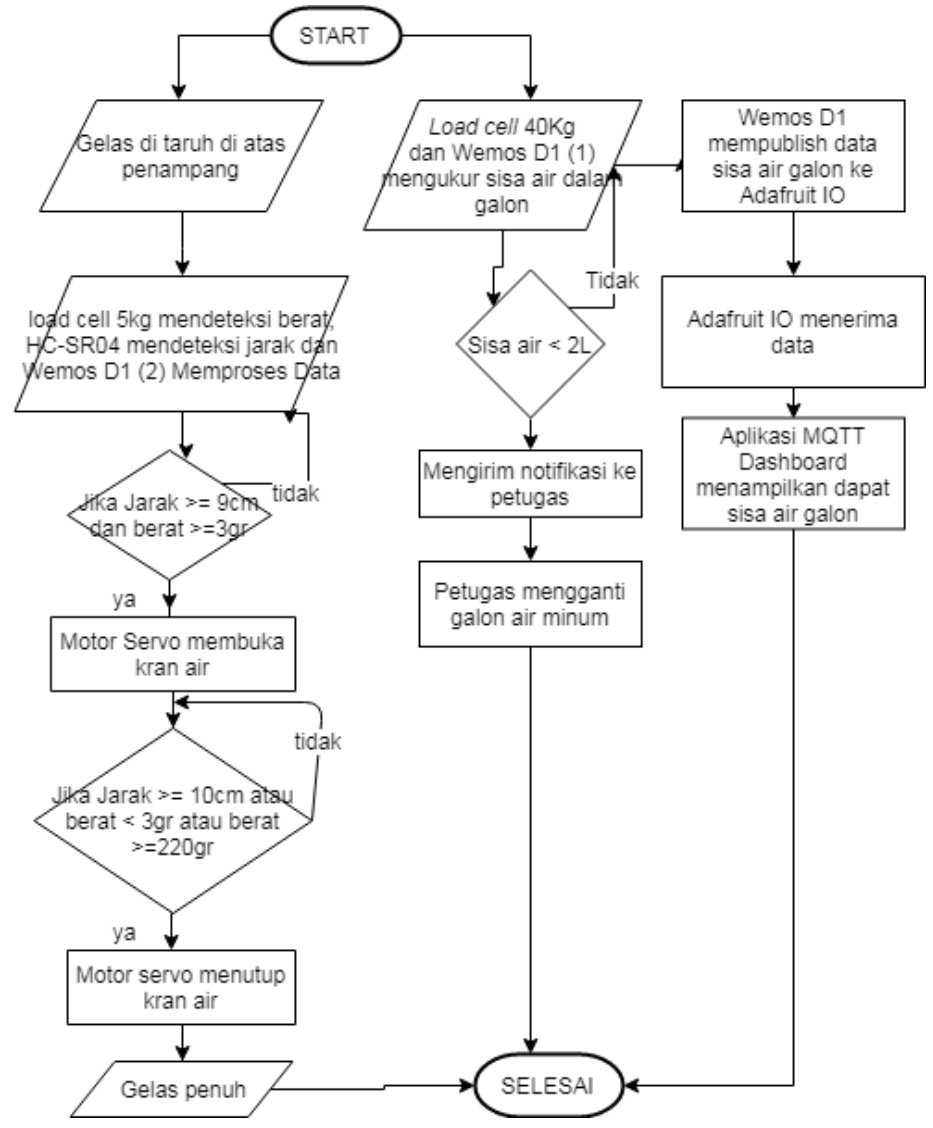

Gambar 3. Flowchart sistem yang diusulkan 


\subsubsection{Cara Kerja Alat}

Ada pun cara kerja alat ini adalah sebagai berikut:

1. Input (Masukan)

a. Load cell $40 \mathrm{Kg}$ sebagai media input untuk mendapatkan nilai sisa air galon berdasarkan berat.

b.HC-SR04 sebagai media input untuk mendeteksi gelas yang ada di atas penampang load cell $5 \mathrm{Kg}$ berdasarkan jarak.

c. Load cell $5 \mathrm{Kg}$ sebagai media input untuk mendeteksi berat gelas kosong dan ketika terisi air.

2. Proses

a. HX711 (1) digunakan untuk merubah nilai input dari load cell $40 \mathrm{Kg}$ yang berupa sinyal analog menjadi sinyal digital sehingga didapat di proses lebih lanjut oleh Wemos D1 (1).

b.HX711 (2) digunakan untuk merubah nilai input dari load cell $5 \mathrm{Kg}$ yang berupa sinyal analog menjadi sinyal digital sehingga didapat di proses lebih lanjut oleh Wemos D1 (2).

c. Wemos D1 (1) memproses data dari HX711 (1) yang kemudian menghasilkan nilai berat dalam dalam satuan $\mathrm{Kg}$ yang setara dengan liter dan kemudian mem-publish datanya ke feeds sisa air galon di Adafruit IO melalui jaringan $W i F i$ yang terkoneksi dengan internet dan mengirim notifikasi ke aplikasi Telegram petugas ketika nilai berat yang dihasilkan mencapai nilai tertentu.

d.Wemos D1 (2) memproses data dari HX711 (2) menggunakan yang kemudian menghasilkan nilai berat dalam dalam satuan gram yang setara dengan $\mathrm{ml}$, memproses nilai jarak yang dihasilkan oleh HC-SR04. Apabila nilai jarak, nilai berat dari load cell $5 \mathrm{Kg}$ mencapai nilai tertentu akan menentukan pergerakan motor servo sehingga kran air terbuka/tertutup.

e. Adafruit IO

Adafruit IO berfungsi sebagai MQTT server yang menerima data sisa air galon dari Wemos D1 (1) dan meneruskannya ke device yang men-subscribe feeds data sisa air galon.

\section{f. Motor Servo}

Motor Servo bergerak sesuai kondisi yang diproses oleh Wemos D1 (2), yang dihasilkan oleh pergerakan motor servo adalah terbukanya atau tertutupnya kran air.

g.MQTT Dashboard MQTT Dashboard men-subscribe feeds data sisa air galon pada Adafruit IO.

3. Output (Keluaran)

a. Kran air terbuka/tertutup yang digerakkan oleh motor servo yang bergerak berdasarkan hasil proses dari Wemos D1 (2).

b.Pesan notifikasi pada aplikasi Telegram terkirim ke petugas ketika nilai berat dari load cell $40 \mathrm{Kg}$ mencapai nilai rendah yang memungkinkan untuk dilakukan penggantian galon kosong dengan yang baru.

c. Aplikasi MQTT Dashboard yang terpasang di smartphone menampilkan data sisa air galon.

\subsection{Tahap Implementasi}

Pada tahap ini dilakukan penerapan sistem yang diusulkan menjadi sebuah alat dengan menyusun seluruh komponen berdasarkan blok diagram dan diagram alir (flowchart) sistem yang didesain.

2.4. Tahap Pengujian

Pada tahap ini dilakukan uji coba menggunakan metode black box. 


\subsection{Tahap Pemeliharaan}

Pada tahap ini dilakukan pemeriksaan terhadap sistem secara periodik agar alat tetap berfungsi sebagaimana mestinya.

\section{HASIL DAN PEMBAHASAN}

Setelah mengimplementasi rancangan yang telah dibuat menjadi sebuah alat selanjutnya adalah mengujinya dengan menggunakan metode black box.

\subsection{Pengujian Sistem Pemantauan}

Tabel 1. Pengujian Sistem Pemantauan

\begin{tabular}{|c|c|c|c|c|c|}
\hline No & $\begin{array}{c}\text { Skenario } \\
\text { Pengujian }\end{array}$ & $\begin{array}{c}\text { Tes } \\
\text { Case }\end{array}$ & $\begin{array}{l}\text { Hasil yang } \\
\text { diharapkan }\end{array}$ & $\begin{array}{c}\text { Hasil } \\
\text { Pengujian }\end{array}$ & $\begin{array}{l}\text { Kesim- } \\
\text { pulan }\end{array}$ \\
\hline 1. & $\begin{array}{l}\text { Menaruh } \\
\text { galon berisi } \\
\text { air di atas } \\
\text { guci }\end{array}$ & 1) & $\begin{array}{l}\text { Sisa air } \\
\text { galon } \\
\text { terpantau } \\
\text { pada } \\
\text { aplikasi } \\
\text { MQTT } \\
\text { Dashboard }\end{array}$ & 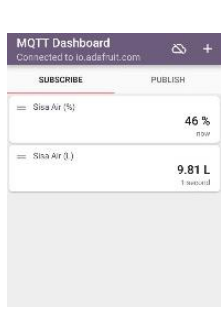 & valid \\
\hline 2 & $\begin{array}{c}\text { Sisa air di } \\
\text { bawah atau } \\
\text { sama } \\
\text { dengan } 2 \\
\text { liter }\end{array}$ & $\begin{array}{l}=-1 \\
=-1 \\
=-1 \\
=-1\end{array}$ & $\begin{array}{l}\text { Mengirim } \\
\text { notifikasi air } \\
\text { habis }\end{array}$ & 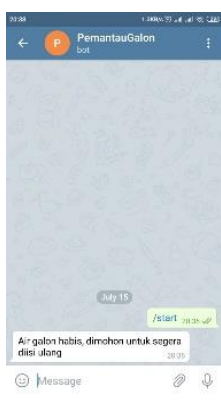 & valid \\
\hline 3. & $\begin{array}{l}\text { Sisa air di } \\
\text { atas } 2 \text { liter }\end{array}$ & $\begin{array}{l}0 \\
5= \\
5=\end{array}$ & $\begin{array}{c}\text { Tidak } \\
\text { mengirim } \\
\text { notifikasi air } \\
\text { habis }\end{array}$ & $\frac{1}{0+m}$ & valid \\
\hline
\end{tabular}

3.2. Pengujian Pengisian Gelas Otomatis

Tabel 2. Pengujian pada saat kran air tertutup

\begin{tabular}{|c|c|c|c|c|c|}
\hline No & $\begin{array}{c}\text { Skenario } \\
\text { Pengujian }\end{array}$ & $\begin{array}{c}\text { Tes } \\
\text { Case }\end{array}$ & $\begin{array}{c}\text { Hasil yang } \\
\text { diharapkan }\end{array}$ & $\begin{array}{c}\text { Hasil } \\
\text { Pengujian }\end{array}$ & $\begin{array}{c}\text { Kesim- } \\
\text { pulan }\end{array}$ \\
\hline
\end{tabular}




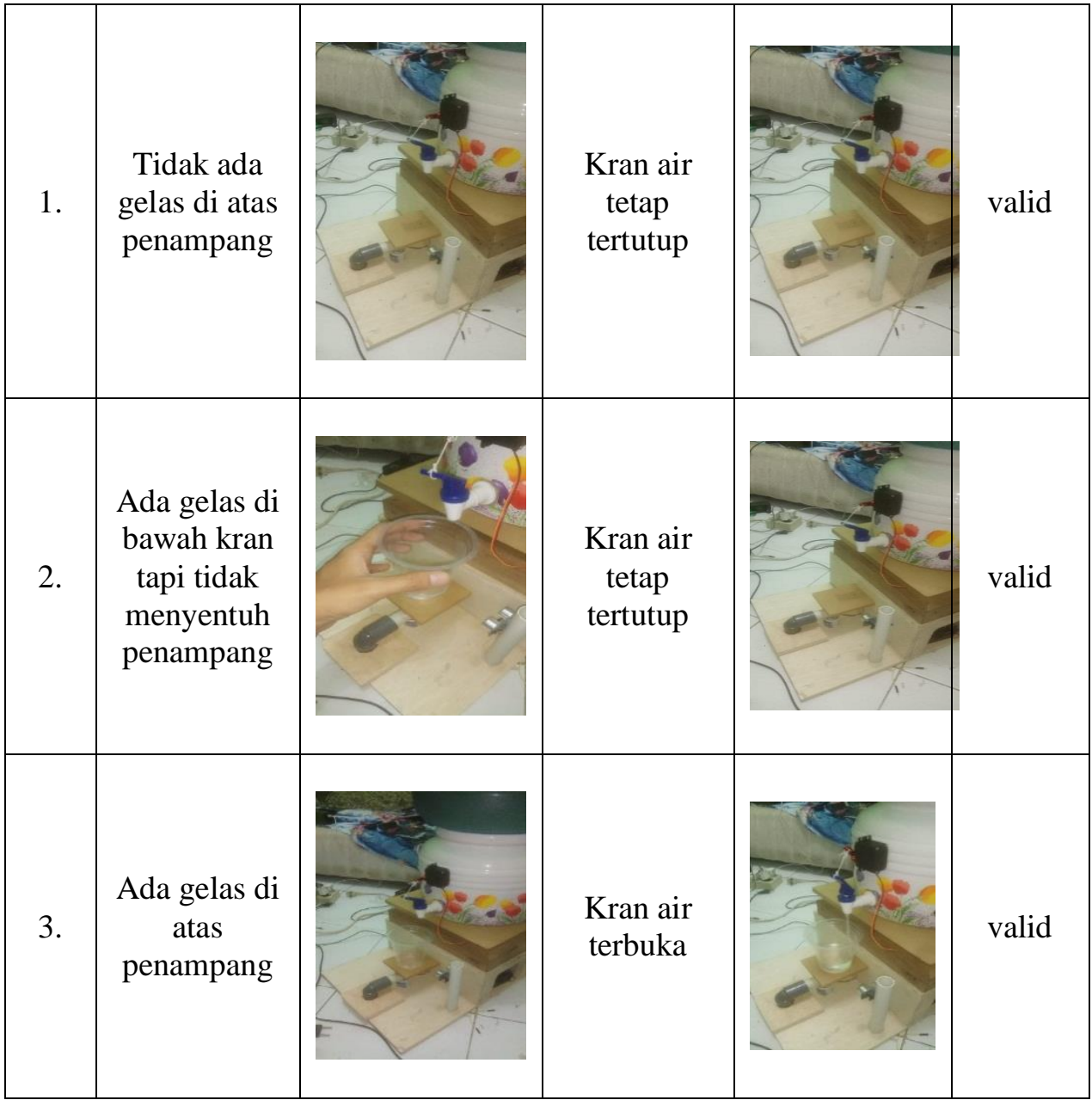

Tabel 3. Pengujian pada saat kran air terbuka

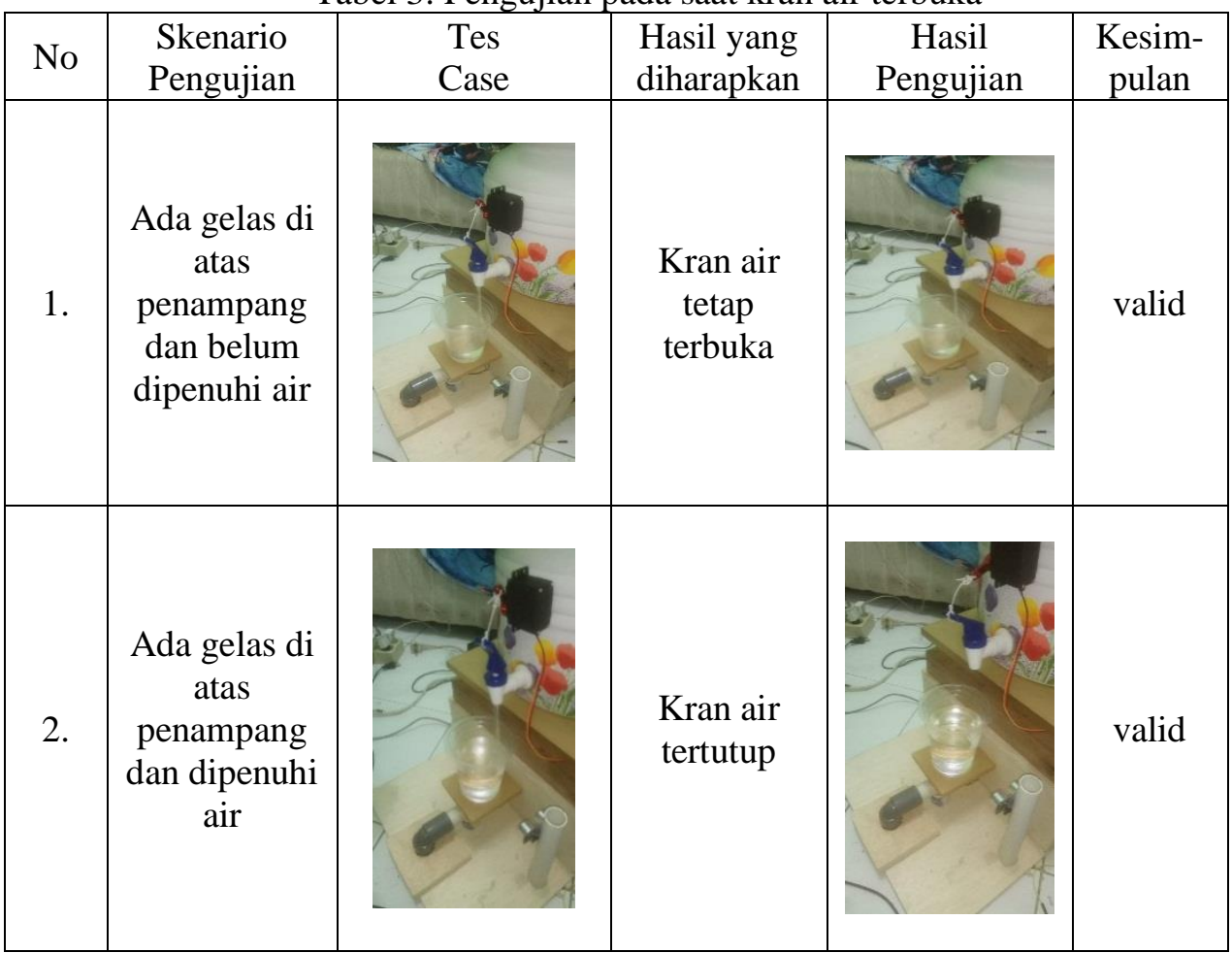




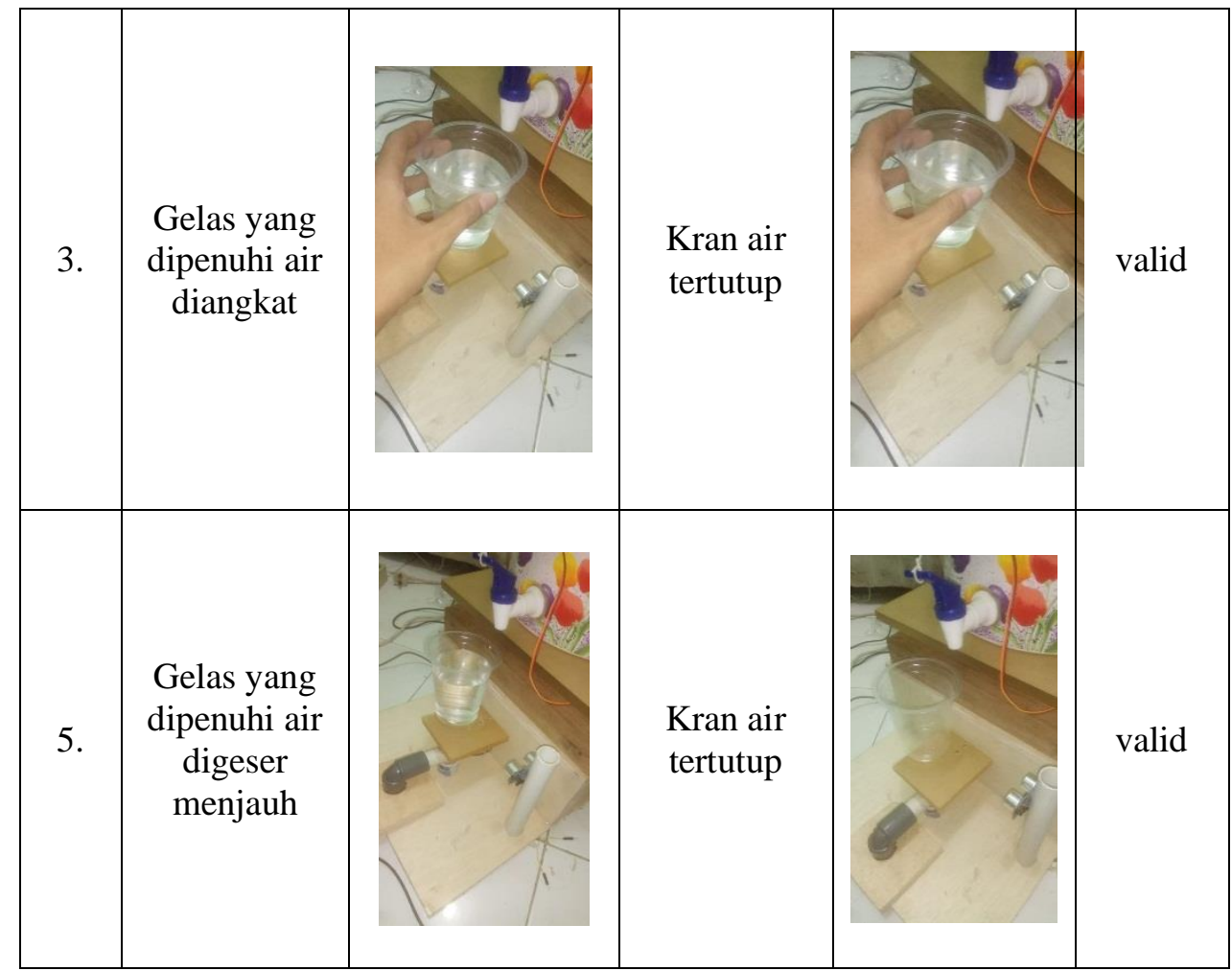

\section{KESIMPULAN}

Dengan menggunakan load cell 40Kg dapat mendeteksi berat air yang ada di dalam galon sehingga sisa air dapat terpantau. Wemos D1 (1) dapat terhubung dengan WiFi dan terkoneksi ke internet sehingga dapat menggunakan Adafruit IO sebagai MQTT server sebagai tempat untuk mem-publish data sisa air galon secara online ke feeds data sisa air galon dan Adafruit IO meneruskan datanya ke device yang terhubung dengan Adafruit IO dengan mensubscribe feeds data sisa air galon menggunakan Aplikasi MQTT Dashboard untuk menampilkan data sisa air galon pada smartphone.

Kapasitas galon adalah 19 liter dan guci penampung air galon berkapasitas hingga 6 liter sehingga ketika sisa air galon 2 liter sudah cukup untuk mengatur kondisi bahwa air galon sudah habis. Dengan menggunakan bot Telegram memungkinkan untuk Wemos D1 (1) mengirim pesan notifikasi kepada petugas yang memberitahukan bahwa air galon sudah habis dan diharapkan untuk melakukan penggantian galon yang kosong dengan yang penuh.

Untuk mendeteksi gelas digunakan dua buah kondisi yaitu load cell $5 \mathrm{Kg}$ untuk mendeteksi berat gelas di bawah 20gr yang dianggap sebagai gelas kosong dan sensor jarak untuk memastikan gelas berada di posisi yang tepat yaitu di bawah kran air galon yaitu berada pada jarak di bawah $8 \mathrm{~cm}$ dan di atas $5 \mathrm{~cm}$ dan menyimpan data berat tersebut sebagai berat gelas. Apabila kedua kondisi tersebut terpenuhi maka Wemos D1 (2) akan memerintahkan motor servo untuk bergerak menarik tuas kran air sehingga air dapat mengalir ke gelas yang kosong. Ketika berat gelas mencapai angka di atas berat gelas $+220 \mathrm{gr}$ maka Wemos D1 (2) akan memerintahkan motor servo untuk bergerak menutup kran air. Air yang dihasilkan dalam gelas adalah $250 \mathrm{ml}$ karena pada saat proses penutupan kran membutuhkan waktu sehingga masih ada air yang mengalir ke dalam gelas.

\section{SARAN}

Berikut ini adalah beberapa saran untuk pengembangan lebih lanjut, yaitu: 
a. Untuk meningkatkan kepastian bahwa yang ada di atas penampang adalah sebuah gelas maka dapat menggunakan kamera dan image processing

b. Pengiriman notifikasi dapat menggunakan metode lain seperti SMS, alarm dan sebagainya untuk mengantisipasi apabila ada gangguan dalam koneksi internet.

\section{DAFTAR PUSTAKA}

[1] Wibowo, A. dan Lawrence A. S. 2019. Analisis Pemakaian Sensor Loadcell Dalam Perhitungan Berat Benda Padat Dan Cair Berbasis Microcontroller. Jurnal ELKOM Vol. 11, No. 1 .

[2] Arifin, A. 2019. 1 Kg Berapa Liter - Rumus, Cara Hitung, Contoh Soal, https://rumusbilangan.com/1-kg-berapa-liter/. Diakses pada Tangga: 13 Agustus 2019.

[3] Supriyono, I. A., Ferry S., Muhammad K. F. 2016. Pengukur Tinggi Badan Menggunakan Sensor Ultrasonik Berbasis Mikrokontroler Atmega328 Dengan Output Suara. CCIT Journal Vol. 9, No. 2.

[4] Apriani, D., Kharis M. dan Ade S. 2019. Alat Monitoring Pada Depo Air Minum Biru Cabang Nagrak Kota Tangerang Menggunakan Air Galon Berbasis Sms Gateway. SENSI Journal Vol.5, No.1.

[5] Suhendra, I. dan Wahyu S. P. 2015. Aplikasi Load Cell Untuk Otomasi Pada Depot Air Minum Isi Ulang. Jurnal Sains dan Teknologi Vol. 1, No. 1.

[6] Widharma, I G. S. 2017. Perancangan Simulasi Sistem Pendaftaran Kursus Berbasis Web Dengan Metode SDLC. Jurnal Matrix Vol. 7, No. 2. 